\title{
Overpressure Transmission through Interconnected Igneous Intrusions
}

Nick Schofield', Simon Holford ${ }^{2}$, Alex Edwards ${ }^{3}$, Niall Mark', Stefano Pugliese $^{4}$

'Department of Geology and Petroleum Geology, University of Aberdeen, Aberdeen AB24 3FX, UK

${ }^{2}$ Australian School of Petroleum, University of Adelaide, Adelaide, SA 5005, Australia

${ }^{3}$ Ikon Science Ltd, I The Crescent, Surbiton, London, KT6 4BN, UK

${ }^{4}$ Chrysaor, Brettenham House, Lancaster Place, London WC2E 7EN

\section{Abstract}

In situ overpressures in sedimentary basins are commonly attributed to disequilibrium compaction or fluid expansion mechanisms, though overpressures in shallow sedimentary sequences may also develop by vertical transfer of pressure from deeper basin levels, for example via faults. Mafic sill complexes are common features of sedimentary basins at rifted continental margins, often comprizing networks of interconnected sills and dikes that facilitate the transfer of magma over considerable vertical distances to shallow basinal depths. Here we document evidence for deep sills (depths $>5 \mathrm{~km}$ ( $16,000 \mathrm{ft}$ )) hosting permeable, open fracture systems that may have allowed transmission of overpressure from ultra-deep basinal $(>7 \mathrm{~km}$ $(23,000 \mathrm{ft}))$ levels in the Faroe-Shetland Basin (FSB), NE Atlantic Margin. Most notably, well 214/28-I encountered overpressured, thin $(<8 \mathrm{~m}(26 \mathrm{ft}))$ and fractured gas-charged intrusions, which resulted in temporary loss of well control. While the overpressure could reflect local gas generation related to thermal maturation of Cretaceous shales into which the sills were emplaced, this would require the overpressures to have been sustained for unfeasibly long timescales (>58 Myr). We instead suggest that transgressive, interconnected sill complexes, such as those penetrated by well $2 \mid 4 / 28-I$, may represent a previously unrecognized mechanism of transferring overpressures (and indeed hydrocarbons) laterally and vertically from deep to shallow levels in sedimentary basins, and that they represent a potentially under- 
recognized hazard to both scientific and petroleum drilling in the vicinity of subsurface igneous complexes.

\section{Introduction}

Abnormally high pore-fluid pressure, commonly referred to as overpressure, is a common occurrence within sedimentary basins, occurring when the pore-fluid pressure is greater than the hydrostatic pressure expected at a given depth (Neglia, 1979; Mann and Mackenzie, 1990; Osborne and Swarbrick, 1997; Tingay et al., 2007). Encountering unexpected overpressure zones during drilling operations can pose a significant risk to both human life, the environment and a well achieving its technical objective; such zones can result in an influx of high pressure gas or fluid into and up the wellbore (known as a 'kick'), and in a worst-case scenario a 'blowout' (Grace, 20I7). Accurate prediction of pore pressures when drilling petroleum wells fundamentally underlies safe drilling operations; the lack of adequate understanding and subsequent response to higher than expected pore pressures during drilling of the Banjar Panji-I well in Java, Indonesia was a contributing factor to the blowout and the flow of the 'Lusi' Mudflow, that suddenly erupted in an urban area, burying over I I,000 buildings (Tingay, 20I5).

It is generally accepted that disequilibrium compaction related overpressure cannot be sustained for long periods of geological time $(>20 \mathrm{Ma})$ within a sedimentary basin, with the overpressure dissipating via fluid leakage (Osborne and Swarbrick, 1997; Swarbrick et al., 200 I; Tingay et al., 2007; Luo and Vasseur, 2016). Critically, it is also generally assumed that overpressure exists close to where it is generated (Osborne and Swarbrick, 1997). The transfer of overpressure horizontally or vertically within sedimentary basins has not been widely documented globally but with a few notable exceptions. Tingay et al. (2007) demonstrated the likely vertical transfer of overpressure up normal faults within the inner 
shelf of the Baram Delta, Borneo. Other notable areas where such pressure transfer is documented is that of the Northern Carnarvon Basin, Northwest Australia Shelf (van Ruth et al., 2000; Dodds et al., 200I; Tingate et al., 200I; Hoskins et al., 20I5) and the Qaidam Basin, northwest China (Fan et al., 2016).

Here we detail the occurrence of overpressure within igneous intrusions in the FaroeShetland Basin (FSB), using a combination of subsurface datasets. We propose a new mode of overpressure transfer via inter-connected networks of fractured igneous intrusions. We then discuss the ramifications of such an 'overpressure' transfer mechanism for both petroleum and scientific drilling in sedimentary basins containing extensive igneous intrusions (e.g. NW Shelf of Australia, South Atlantic Margin, Norwegian Margin, Guaymas Basin), emphasizing the need to plan for the possibility of encountering significantly higher than expected pore-fluid pressures in the vicinity of igneous sheet intrusions.

\section{Geological History and Petroleum Exploration History of the Faroe-Shetland Basin (FSB)}

The FSB is located between the Faroe Islands and Shetland Islands within the Atlantic passive continental margin of NW Europe (Fig. I). The FSB can be divided into a series of SW-NE trending sub-basins and is quasi-contiguous with the Rockall Trough to the SW and the Møre Basin to the NE (Hitchen and Ritchie, 1987). The sub-basins consist of Mesozoic to Recent sediments bounded by basement highs comprised of Precambrian crystalline rocks capped by Palaeozoic and Mesozoic sediments (Lamers and Carmichael, 1999).

The tectonic evolution of the FSB is complex and encompasses a number of rifting phases and compressional events that span a time period of c. 400 Myr, from the Devonian to the Cenozoic. Much of the present-day structure and past rifting history is thought to have been heavily controlled by the NE-SW trending basement grain which formed throughout 
NW Scotland during the Caledonian Orogeny during the Ordovician to early Devonian. The first widespread phase of rifting within the basin was initiated during the Permo-Triassic, taking place along the existing NE-SW Caledonian structural grain. This produced a series of halfgraben basins filled with fluvial, eolian and lacustrine sequences. Thermal subsidence and rising global sea level led to a Lower Jurassic marine incursion (Booth et al., 1993), with thermal subsidence continuing into the Middle Jurassic. Into the Upper Jurassic, the FSB underwent renewed rifting, linked to the establishment of extensive rifting within the North Sea. However, detailed evidence of Upper Jurassic extension within the FSB is limited by poor seismic imaging beneath the Paleocene-Eocene sill complex (Schofield et al., 20I5). The early Cretaceous was marked by high magnitude extension as a result of the northwards propagation of the Central Atlantic Rift system (Fleet and Boldy, 1999; Stoker, 2016), leading to hyper-extension along the NE Atlantic Margin (Dore et al., 1997; Booth et al., 1993; Moy and Imber, 2009).

The North Atlantic rift system became relatively inactive during the Upper Cretaceous, with post-rift thermal subsidence facilitating the deposition of up to $4.5 \mathrm{~km}$ (I4,763 ft) of Upper Cretaceous sediments on the downthrown side of the major fault systems. During the Paleocene, relative deepwater marine conditions existed with deposition of hemi-pelagic shales and turbidite sandstones (Lamers and Carmichael 1999) as part of continued post-rift thermal subsidence.

However, during the late Paleocene-early Eocene the FSB experienced considerable igneous activity as a result of the impinging proto-Icelandic plume coinciding with continental break-up of the North Atlantic (White and McKenzie, 1989). This igneous activity is expressed by the eruption of extrusive basaltic sequences and the emplacement of a pervasive suite of mafic sills and dykes into the sedimentary basins flanking the NE Atlantic Margin (Fig. 2) (Gibb and Kanaris- Sotriou, 1998; Schofield et al., 2015). Mafic intrusions are identified throughout 
the FSB where they are collectively termed the Faroe-Shetland Sill Complex (FSSC), and extending northwards into the Møre basin and south into the Rockall Trough (Schofield et al., 2017). Critically the FSSC, and the sills in other Atlantic Margin basins, are observed to preferentially intrude the Cretaceous and lower Paleocene sedimentary succession, which is predominantly composed of marine shales (Stoker et al., 2016) and represents a significant low-permeability sealing unit (Ogilvie et al., 20I5).

The FSB has seen active exploration for the last 50 years with the first well (206/I2I) drilled in 1972 on the Rona Ridge, and over 200 exploration and appraisal wells in total drilled in the FSB. Reservoirs are present throughout the entire basin succession, from fractured Lewisian Gneiss crystalline basement (Lancaster Field), the fractured siliclastics in the Devonian and Carboniferous Old Red Sandstone (Clair Field), Jurassic sandstones (Lochnagar Discovery), Cretaceous (Victory Discovery and Edradour Field), Paleocene turbidites (Schiehallion, Laggan-Tormore, Glenlivet Fields and Cragganmore Discovery), Paleocene-eocene intra-basaltic fluvial deltaic sandstones (Rosebank Field), Lower Eocene supra-basaltic sandstones (Cambo Field) and Mid-Eocene turbidite fan sandstones (Tobermory Discovery). The majority of hydrocarbons discovered are sourced from the marine Upper Jurassic Kimmeridge Clay Formation, though in some areas Middle Jurassic lacustrine (Scotchman et al., 20 I8) and Middle Devonian lacustrine (Baron et al., 2008) sources are thought to contribute.

\section{Overpressure Development within the Faroe-Shetland Basin}

Understanding the interplay of pore pressures and their impact on petroleum generation during basin evolution is essential for any petroleum exploration and has particular importance in the Faroe-Shetland Basin due to the tectonic complexity (Iliffe et al., 1999). Despite extensive exploration activity in the FSB, a full quantitative analysis of the depth-pore pressure 
relationships remains poorly documented in the literature. However, some broad conclusions can be drawn about the pressure history of the FSB.

Measured reservoir pressure data show that the majority of the wells in the West of Shetlands region exhibit normally pressured or near-normally pressured gradients (lliffe et al., 1999; Lamers and Carmichael, 1999; Edwards et al., 2012). However, overpressure is known to occur within Mesozoic sections at depths $>3,000 \mathrm{~m}(9,842 \mathrm{ft})$, with Lower Cretaceous sequences generally exhibiting the largest formation overpressures (Iliffe et al., 1999; Tassone et al., 20I4). The distribution of overpressure within the FSB is, however, not uniform with both normally pressured and overpressured high permeability sands occurring at similar depths. This implies that a complex basin plumbing and fluid drainage system is in operation within the FSB (Edwards et al., 20I2). It is generally accepted that disequilibrium compaction, as a result of high sedimentation rates in the Cenozoic, is the dominant mechanism that has created the large magnitude (> $20 \mathrm{MPa}(2,90 \mathrm{I}$ psi)) overpressure within the Mesozoic sections of the FSB (Iliffe et al., 1999). The observation in velocity-density cross-plot space, in absence of XRD-type data, show there are no deviations of data from a normal compaction trend and hence, supports the notion that disequilibrium compaction is primarily active (Fig. 3). It should also be noted that although the FSB has undergone multiple phases of tectonic uplift (Stoker et al., 2010) the two wells of interest in this study are located in sub-basins that have undergone negligible uplift, as demonstrated by Cretaceous shale compaction data (Tassone et al., 2014).

\section{Overpressured Intrusions}

Well 2 I 4/28-I - Flett Ridge

Well $214 / 28-1$, drilled in the FSB in 1984 to a total depth of 5,124 meters below rotary table (mBRT) (16,8I I ft BRT) (653 m (199 ft) water depth), was designed to test Paleocene and 
Jurassic targets (Grove, 2013). However, the well encountered substantial issues with overpressured mafic intrusions between 4,596 mBRT (I5,078 ft BRT) and 5,013 mBRT (I6,446 ft BRT) (Fig. 4), which required the expenditure of considerable time and effort to control the overpressure and gas influx (Mark et al., 2017). The intrusions penetrated by Well 2I4/28-I form a series of vertically stacked intrusions that extend down towards the centre of the Flett Basin and the base of the Cretaceous sequence (Schofield et al., 20I5) (Fig. 2).

Using direct (e.g. Wireline formation tester-WFT, Repeat formation tester-RFT and Modular formation dynamic tester-MDT) and indirect (e.g. mud weights), pressure data indicates a consistent picture of broadly hydrostatic pressures to depth of $\sim 3,200 \mathrm{~m}(10,498$ $\mathrm{ft}$ ) within the middle Paleocene (Fig. 5). Below this depth, RFT and MDT data begin to indicate a departure from normal hydrostatic conditions and occurrence of overpressure, which increased gradually with small deviations (e.g. 4,100 mBRT; $|3,45| \mathrm{ft}$ BRT). The top of overpressure was estimated using intermediate wireline logs during drilling operations and was found at approximately 4,480 mBRT (I4,698 ft BRT) (Fig. 5). This depth is consistent with regionally built shale-models in the West of Shetlands Region (Edwards et al., 2012; Tassone et al., 20l4). However, on encountering a $6.1 \mathrm{~m}$ (20 ft) thick intrusion at a sub-seabed depth of 4,596 mBRT (I5,075 ft BRT) (Fig. 4, 5, and 6), a large magnitude overpressure was encountered associated with high pressure gas influx into the wellbore and $44 \%$ Total Gas (Methane, Ethane, Propane and Butane) (Fig. 5 and 6). Using the static mud weight pressure as a proxy for pore pressure in absence of direct pressure data (e.g. RFT) at this interval (van Ruth et al., 2002), the circulating mud weight had to be increased to control the pore pressure increase and associated gas from around $57 \mathrm{MPa}(8,267 \mathrm{Psi}$; I0.5 PPg) to over 7I MPa (I0,296 Psi; I3.I PPg) (Fig. 5 and 6). On continuation of drilling, with the increased mud weight, two further intrusions where penetrated at 4,788 $\mathrm{mBRT}($ I5,708 ft BRT) and 4,93I mBRT (I6, I77 $\mathrm{ft} \mathrm{BRT}$ ) respectively, with no further influx of gas noted (Fig. 6). However, at a depth of 5,0I3 
mBRT (I6,446 ft BRT), a $7.6 \mathrm{~m}$ (25 ft) thick overpressured intrusion was encountered (Fig. 6), with mud weights having to be raised further to counteract estimated pressure of over 82 MPa (I I,893 Psi; I 3.9 PPg). Associated with this intrusion was 5 I\% Total Gas (Methane), which when expanding at the surface led to mud flowing out over the Kelly Bushing and partial loss

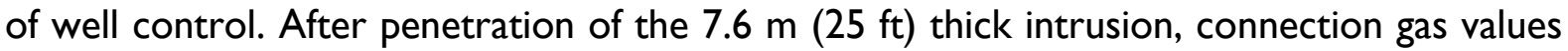
remained at $30-45 \%$ even at the increased levels of mud weight to the base of hole at 5,124 $\operatorname{mBRT}(|6,8| \mathrm{It} B R T)$.

\section{Well 2/9/28-2Z - Northern FSB}

Well 219/28-2Z was drilled to a total depth of 4,016 mBRT (I3, I75 ft BRT) (5I6m (I692 ft) water depth) in the north east of the FSB and southern extension of the Møre Basin, approximately $20 \mathrm{~km}$ (12 miles) northwards of the Margarita Spur. The well penetrated a 36 $\mathrm{m}$ ( I $18 \mathrm{ft}$ ) thick intrusion at 3, I $48 \mathrm{mBRT}(10,328 \mathrm{ft}$ BRT) ( 3.I sec TWT) (Fig. 7 and 8). On seismic data, the intrusion is poorly imaged due to the deep depth of imaging and inclined (approximately $40^{\circ}$ ) nature of the intrusion. However, the intrusion can be seen to connect sub-vertically to a series of sills intruded into the Lower Cretaceous succession. Although initially, the intrusion (which was associated with a small gas peak ranging from 0.78 to $1.92 \%$ ), was estimated to have a pore pressure of between $39 \mathrm{MPa}(5,706 \mathrm{Psi} ; 10.5 \mathrm{ppg})$ and $40 \mathrm{MPa}$ (5,923 Psi; 10.9 PPg), a direct RFT measurement taken at the lower intrusion contact gave a pore pressure measurement of $48 \mathrm{MPa}$ (6,956 Psi; $12.8 \mathrm{PPg}$ ) (Fig. 8 and 9) with the well completion report noting that the high pore pressure was probably confined entirely to the sill and that the adjacent claystone appeared to have been at a substantially lower pressure gradient.

\section{Discussion}




\section{Overpressure Generation}

Although fluid expansion can take place by a variety of mechanisms (e.g. aquathermal expansion, diagenesis; see Tingay et al., 20I3), kerogen to gas maturation is generally regarded as the dominant fluid expansion mechanism by which high magnitude overpressure, equivalent to that formed by disequilibrium compaction can be generated (Swarbrick and Osborne, 1998; Tingay et al., 2007). The emplacement of mafic, Paleogene-age intrusions into the Cretaceous claystone sequences of the FSB could lead to gas generation, as a result of localized maturation of organic matter by the intrusions (Aarnes et al., 2010; Muirhead et al., 2017). However, we argue against this mechanism for the overpressure witnessed within the intrusions penetrated in 2I4/28-I and 219/28-2Z. First, multiple studies have shown that petroleum source potential is generally lacking in the Cretaceous and Cenozoic stratigraphy and hence the local host rocks are likely to be poor source rocks for gas (Scotchman, 200I; Scotchman, 20I8). Second, overpressures are inherently unstable, with pore-fluid pressures always attempting to return to hydrostatic equilibrium (Osborne and Swarbrick, 1997). The residence time of overpressure related to disequilibrium compaction is generally less than $20 \mathrm{Ma}$ (Lou and Vasseur 2016). Therefore having overpressure maintained from $58 \mathrm{Ma}$, when the sills were emplaced, would exceed the generally accepted upper maximum timescale in which overpressure is thought to be sustainable within most sedimentary basins.

\section{Fractures within Intrusions}

Exposed basaltic sill intrusions are often pervaded by open fractures, both vertical and horizontal, in the form of cooling joints, which can create substantial fracture connectivity (Bemudez and Delpino, 2008; Rateau et al., 2012; Senger et al., 2015). However, because of the unloading associated with the exhumation of such intrusions to contemporary surface 
levels, it is often difficult to assess whether open fractures visible in surface outcrops (e.g. Senger et al., 2015), would still be open and interconnected in deeply buried intrusions.

Multiple intrusions encountered within the FSB have caused substantial mud losses during drilling (Rateau et al., 20 I3; Mark et al., 20I7). In an extreme case, 23,000 bbl of drilling mud was lost into a $60 \mathrm{~m}$ (197 ft) thick, fractured intrusion in the FSB (208/I5-IA; Mark et al., 2017). In total, of the 29 wells that have encountered intrusions in the FSB, $>80 \%$ have suffered some degree of mud loss when drilling through intrusions (Rateau et al., 2013; Mark et al., 2017).

Additionally, open fractures within intrusions along Atlantic Margin have been inferred to control the location of oil and gas accumulations (e.g. Tormore Field), by acting as migration 'super-highways' through low permeability Cretaceous sequences (Rateau et al., 20I3; Schofield et al., 2015; Schofield et al., 2017). In Svalbard, the intrusions and surrounding contact metamorphic aureoles have been inferred to control fluid flow and gas escape structures adjacent to intrusions on the seafloor (Senger et al., 20I3).

The open nature of fractures within subsurface igneous intrusions, even at depth, can be substantiated directly, when available, from borehole image resistivity logs (e.g. FMI Formation Micro Imager, AFR - Azimuthal Focused Resistivity, OMRI - Oil Mud Reservoir Imager). In Figure 10, a FMI log through an igneous intrusion encountered at 3,265 mBRT $(I 0,7 \mathrm{I} I \mathrm{ft} B R T)$ within the subsurface shows clear evidence of open horizontal and vertical fractures within a $27 \mathrm{~m}(88 \mathrm{ft})$ thick intrusion. We interpret the sub-vertical fractures, which extend $>30^{\circ}$ around the circumference of the hole, to be primary cooling fractures and not drilling induced, as no sub-vertical fractures are seen in the weaker shale horizons above and below the intrusion, and no change in mud weight occurred while drilling from the shale through to the intrusion. Additionally, core obtained from intrusions within the FSB have also 
been shown to contain open vertical and importantly horizontal natural fracture sets (i.e. not induced by drilling) (Rateau et al., 2013; Grove, 2019, pers. comm.).

Associated with the fractures observed in the FMI log in Figure 10 is an increase in separation between the logged medium and deep resistivity within the wireline logs. In the areas of clear fracturing on the FMI Log (Fig. I0), the medium resistivity, which measures the rock and pore fluids close to the wellbore $(\sim 1.5 \mathrm{~m}(5 \mathrm{ft}))$, is lower due to the invasion of the water-based mud into the sill via the fractures (thus reducing resistivity). The deep resistivity, however, remains high as it is measuring the virgin formation further away from the borehole where the formation has not been invaded by the water-based mud. This same resistivity separation relationship appears to be demonstrated within well $219 / 28-2 Z$, where the resistivity separation within the intrusion where the elevated pore pressure was recorded by the RFT can be seen clearly (Fig. 8).

In the case of well $214 / 28-I$, the main evidence for presence of fractures is the occurrence of the gas related 'kicks' associated with the $6.1 \mathrm{~m}(20 \mathrm{ft})$ and $7.6 \mathrm{~m}(25 \mathrm{ft})$ thick intrusions (Fig. 5 and 6). As intrusions usually possess zero effective primary inter-granular porosity, permeability is usually created by presence of interconnected primary or secondary fractures (Bemudez and Delpino, 2008; Rateau et al., 2013).

Interpretation of resistivity profiles in well $214 / 28-I$ is complicated as the section in which the intrusions are present was drilled with an invert emulsion oil-based mud (IEOM). Within the suite of intrusions that overpressure was encountered (Fig. 6), a clear separation in resistivity is visible within two of the sills implying potential open fractures within the intrusions. However, this relationship is inverse to what would be expected with an oil-based mud, and therefore in the absence of image log data (which was not collected) and other uncertainties (e.g. water saturation in the intrusion) it is difficult to interpret the resistivity separation as being fracture-related with total confidence. Interestingly a resistivity separation 
is not visible within the two overpressured intrusions (detailed previously). This lack of resistivity separation could be the result of the drilling mud being unable to invade into the fracture network of the intrusion, due to the outward force of the gas (although balanced during logging), preventing the invasion of the drilling mud into fractures, thus preventing a resistivity contrast.

The intrusions within the FSB have never been exhumed or substantially uplifted since their emplacement. This suggests the fractures found in the intrusions at depth are probably the result of normal cooling and contractional processes within the intrusions at the time of emplacement (Bemudez and Delpino, 2008). When the fractures became open is more difficult to assess and still unclear, although compressional inversion did take place within the FSB from the Miocene-Oligocene, which may have reactivated existing fractures or created new fractures within the intrusions (Ritchie et al., 2008).

\section{'Overpressure' transmission via fractured sills}

Igneous intrusions within sedimentary basins often form highly interconnected complexes; Cartwright and Hansen (2006) documented this phenomenon on the Norwegian Margin, showing a complex of interconnected sill intrusions extending over $12 \mathrm{~km}$ (7.5 miles) vertically and $20 \mathrm{~km}$ (12.4 miles) horizontally. Similar, highly interconnected complexes of mafic intrusions are also observed in the FSB (Schofield et al., 20I5) (Fig. 2)

In the specific case of the intrusions penetrated by well 2 I4/28-I, seismic reflection mapping shows that the overpressured intrusions form part of a larger, interconnected intrusive complex that can be traced toward the center of the basin, 'rooting' at depths $>6$ km (I9,685 ft) (Fig. II) (Schofield et al., 20I5; Mark et al. 20I7). A continuous path can be traced from the $6.1 \mathrm{~m}(20 \mathrm{ft})$ thick overpressured intrusion penetrated by well $2 / 4 / 28-\mathrm{I}$ at 
4,596 mBRT (I5,075 ft BRT), via the interconnected intrusion to over $6 \mathrm{~km}(19,685 \mathrm{ft})$ in depth (Fig. II) on 3D seismic data.

In well $219 / 28-2 Z$, the overpressured sill can be seen to be connected from $\sim 3, \mid 48$ mBRT $(10,328 \mathrm{ft} B R T)$, where it was penetrated by the well to a "saucer-shaped" intrusion situated in the Lower Cretaceous at a depth of $\sim 4,300 \mathrm{mBRT}(\mathrm{I} 4,108 \mathrm{ft}$ BRT) (Fig. 7). The saucer-shaped intrusion can be seen to be connected to a further inclined intrusion that extends down to a depth of $\sim 7 \mathrm{~km}(22,965 \mathrm{ft})$ within the Lower Cretaceous (Fig. 7).

Therefore, given the interconnected nature of intrusions, coupled with the evidence supporting the occurrence of open fracture systems within the intrusions, it seems plausible that intrusions may act as fractured conduits, hydraulically connecting separate pressure regimes within a basin. This would lead to apparent 'overpressure' if intersected within the subsurface, even though the overpressure is the result of pressure transmission from a deeper sequence.

A common concept used to explain the presence of overpressure within reservoir sand units is that of the centroid (Fig. 12) (Traugott and Heppard, 1994; Swarbrick and Osborne, 1998), where lateral pressure transfer occurs through a sand body which has become inclined (Swarbrick and Osborne, 1998). The centroid is the depth where the pore pressure in the reservoir and bounding shale are in equilibrium, above the centroid, the pore pressure in the reservoir is higher than that of the bounding shale. Below the centroid, the reservoir pressure will be less than the surrounding shale (Traugott and Heppard, 1994). Tingay et al. (2007) adapted this concept to illustrate that overpressures could be transferred if an overpressured compartment comes into hydraulic communication with another less pressured and isolated compartment either by cap-rock fracturing or active faulting.

In the case of the abnormally pressured intrusions within wells $214 / 28-1$ and $219 / 28$ $2 Z$, both suites of intrusions were penetrated by the wells situated near to the intrusion tip 
and therefore the shallowest depth of the entire intrusive complexes, which can be seen to have climbed sub-vertically, cross-cutting the stratigraphy over distances $>$ I km $(\sim 3000 \mathrm{ft})$ vertically. Given the known overpressure that occurs within the shale-dominated Cretaceous succession of the FSB (Illiffe et al., 1999), it seems plausible that transference of pressure is occurring through the fractured intrusions, under a similar mechanism as proposed by Tingay et al. (2007). However, whereas the models of Tingay et al. (2007) and others are primarily concerned with generally sub-vertical to vertical transfer of overpressure, because of the highly interconnected, laterally extensive nature of the intrusive complexes, overpressures in the FSB could potentially be transferred laterally (and vertically) through a basin up to I0's of km's away from the point of origin. Additionally, unlike the concept of the centroid, which relies on recent tilting of the sand body to produce differential pressures, in the case of intrusions, it is their cross-cutting nature and tendency to intrude sub-vertically which leads to the pressure transfer and fluid drainage (Fig. I2).

It is important to acknowledge that open fracture systems within intrusions are not universally prevalent within the FSB, and fractures can often be infilled by later fracture filling cements (Rateau et al., 2013). Additionally, even if fractured, not all intrusions will carry overpressure. Out of the 29 wells which drilled intrusions within the FSB, only two of the wells, listed in this study, penetrated intrusions that had associated overpressure.

For an intrusion to become overpressured in the subsurface, it must satisfy several criteria. It must contain an open an extensive fracture network, be connected into a deeper pressure regime, and also be sealed by a suitable sealing lithology. If the intrusion intersects a permeable sand sequence, the overpressure will potentially bleed off into that sequence.

Drilling Hazards: Are there safety and potential environmental issues with Petroleum and Scientific (e.g. IODP) exploration in volcanically-influenced basins? 
352 Accurate prediction of subsurface fluid pressures is a critical element of all drilling, underpinning the design of safe wells (Board, 20I2). Critically, pore pressure prediction underpins the well design. For example, the maximum pressure tolerance of a blowout preventer, and even the amount of barite and other chemicals kept on board a drilling rig to enable a rapid change in mud density, are all reliant on predicting the likely pressure at a given depth. In mature basins, such as the North Sea, UK, or established areas of the Gulf of Mexico, where abundant primary well data exists, such prediction is generally well constrained, but in frontier areas, with sparse well control, pore pressure prediction can be highly challenging. Petroleum exploration wells are designed to be able to deal with (within a given tolerance) excess pore pressures. However, IODP (International Ocean Drilling Program) riserless drilling is conducted with no BOP and primarily using seawater as the drilling fluid, meaning no primary (other than seawater) or secondary barrier exists to contain a potentially overpressured zone of fluids. The risk of encountering subsurface overpressure on IODP expeditions drilling is usually minimized as zones of known potential overpressure (e.g. accretionary wedges; Westbrook and Smith, 1983) are avoided. Additionally, many expeditions target objectives within a few hundred meters of the seabed, which can be assumed to be in hydrostatic equilibrium from seabed to the eventual termination point of the well. However, IODP drilling in basins effected by volcanism may be at risk from intersecting sheet intrusions connected to a deeper pressure regime, especially in deeper targets $(>1,000 \mathrm{~m}(\sim 3000 \mathrm{ft})$ below sea floor $)$, where the strength of host rock and sealing capacity may be sufficient to support overpressure connection via an interconnected intrusion to a deeper pressure compartment.

The maximum overpressure that can occur at a given depth is reliant on the sealing capacity of the host lithology in which an overpressured body is situated (Cartwright et al., 2007). The most effective lithologies at containing pressure are those with low permeabilities, 
including shales and mudstone, which sills are known to preferentially intrude (Schofield et al., 20I2). The maximum overpressure that can be supported by a rock unit can be expressed in terms of the fracture gradient of the host rock (e.g. Fig. 4), beyond which hydraulic fracturing and capillary leakage will take place and any overpressure can be assumed to dissipate. Following this scenario, a well being drilled in a geological sequence containing interconnected sill complexes, may have only planned to drill to a depth of e.g. 4,000 mBRT (I3, I23 ft BRT). However, if a fractured intrusion that is part of an interconnected complex plumbed into a deeper overpressure zone was penetrated, a overpressure magnitude up to the fracture gradient of the host rock could be encountered (Fig. I3).

If during planning of the well, this scenario has not been identified, then the well design may not have the inbuilt tolerances to resist the abnormal pressures, leading to a worst-case scenario of a blowout, which brings a substantial risk to human life and the environment.

\section{Recommendation for both Scientific (e.g. IODP) and Petroleum Drilling}

Sill intrusions have a fundamental underlying geological relationship in terms of thickness that directly impacts on their ability to be imaged successfully using seismic reflection data. From studies of both well and field data, around $60 \%$ of intrusions fall under $10 \mathrm{~m}$ in thickness within sedimentary basins globally (Button and Cawthorn, 20I5, Schofield et al., 20I5; Mark et al., 2017; Eide et al., 20 I8; Svensen et al., 2018). This aspect, on its own may not appear significant, but when it is considered in the context of the limitations of imaging of seismic reflection data, this can become an issue. Vertical seismic resolution in seismic surveys is typically in the range of I0s of meters (Cartwright et al., 2005), and at deep basin levels, e.g. 3-4 km's (9842I3, I $23 \mathrm{ft}$ ), vertical resolution can drop to $40-80 \mathrm{~m}(\mathrm{I} 3 \mathrm{I} \mathrm{ft}-262 \mathrm{ft}$ ) range (Schofield et al., 20I5). In the case of potential pressure transmission via intrusions, this is troublesome, as it means that even if intrusions cannot be confidently interpreted from seismic reflection data 
in the vicinity of a well, they may still be present. This is illustrated in well $2 / 4 / 28-I$, where the pressure kicks emanated from intrusions that were $6.1 \mathrm{~m}(20 \mathrm{ft})$ and $7.6 \mathrm{~m}(25 \mathrm{ft})$ thick respectively.

In areas containing pervasive subsurface intrusions, mitigating and predicting the risk of which intrusions may be fractured and overpressured is challenging. Detailed seismic mapping of intrusions may indicate deep connectivity, allowing some degree of mitigation during the well planning phase. During drilling activities, look-ahead resistivity tools (Constable et al., 2016) have the potential to alert drillers to the presence of sub-seismic intrusions before they are encountered, however such tools are in a fledging stage of development (Constable et al., 2016). Additionally, there is a paucity of data on the lookahead resistivity response of intrusions to permit assessment to whether an intrusion is either fractured, not fractured or fractured and overpressured.

In both scientific and commercial drilling operations in basins affected by intrusive volcanism, decisions should be underpinned by the recognition that the majority of intrusions will not be visible on seismic data, and that intrusions in the region of a few meters (I0's of feet) are potentially capable of pressure transmission (Schofield et al., 20I5; Mark et al., 20I7).

\section{Conclusions}

We have detailed the occurrence of overpressure within intrusions of the FSB and propose a new pathway for overpressure transfer within sedimentary basins, namely the lateral and vertical transmission of pressure via vertically interconnected, fractured igneous intrusions. This mechanism is previously unrecognized and may represent a significant hazard to both scientific (e.g. IODP) and drilling for oil and gas in the vicinity of interconnected transgressive igneous intrusive complexes in basins worldwide that contain substantial intrusive igneous 


\section{References}

Aarnes, I., Svensen, H., Connolly, J.A. and Podladchikov, Y.Y., 2010. How contact metamorphism can trigger global climate changes: Modelling gas generation around igneous sills in sedimentary basins. Geochimica et Cosmochimica Acta, 74(24), pp.7179-7I95.

Baron, M., Parnell, J., Mark, D., Carr, A., Przyjalgowski, M. and Feely, M., 2008. Evolution of hydrocarbon migration style in a fractured reservoir deduced from fluid inclusion data, Clair Field, west of Shetland, UK. Marine and Petroleum Geology, 25(2), pp. I53-172.

Bermúdez, A. and Delpino, D.H., 2008. Concentric and radial joint systems within basic sills and their associated porosity enhancement, Neuquén Basin, Argentina. Geological Society, London, Special Publications, 302(I), pp.185-198.

Board, M., 2012, Macondo Well Deepwater Horizon Blowout: Lessons for Improving Offshore Drilling Safety. National Academies Press.

Booth, J., Swiecicki, T. and Wilcockson, P., 1993, January. The tectono-stratigraphy of the Solan Basin, west of Shetland. In Geological Society, London, Petroleum Geology Conference series (Vol. 4, No. I, pp. 987-998). Geological Society of London.

Bowers, G., 1994, Pore pressure estimation from velocity data: accounting for overpressure mechanisms besides undercompaction. Society of Petroleum Engineers Paper 27488, International Association of Drilling Contractors/Society of Petroleum Engineers Drilling Conference: Dallas, p. 5I5-530.

Bowers, G.L., 1995, Pore pressure estimation from velocity data: Accounting for overpressure mechanisms besides undercompaction: SPE Drilling and Completion, v. 10, p. 89-95.

Button, A., and R. G. Cawthorn. "Distribution of mafic sills in the Transvaal Supergroup, northeastern South Africa." Journal of the Geological Society 172.3 (2015): 357-367.

Cartwright, J., \& Huuse, M. (2005). 3D seismic technology: the geological 'Hubble'. Basin Research, I7(I), I-20.

Cartwright, J. and Møller Hansen, D., 2006. Magma transport through the crust via interconnected sill complexes. Geology, 34(II), pp.929-932.

Cartwright, J., Huuse, M. and Aplin, A., 2007. Seal bypass systems. AAPG bulletin, 91(8), pp. I I4I-II66.

Constable, M. V., Antonsen, F., Stalheim, S. O., Olsen, P. A., Fjell, O. Z., Dray, N. Tan, S. (2016, October I). Looking Ahead of the Bit While Drilling: From Vision to Reality. Society of Petrophysicists and Well-Log Analysts.

Deming, D., 1994. Factors necessary to define a pressure seal. AAPG bulletin, 78(6), pp. 1005-1009.

Dodds, K., Flecher, A., Bekele, E.b. Hennig, A.L., Johnson, M. D. Abriel, W., Higgs, W.G. and Strudley, A. 2001. An overpressure case history using a novel risk analysis process. APPEA Journal 559-57I.

Doré, A.G., Lundin, E.R., Fichler, C. and Olesen, O., 1997. Patterns of basement structure and reactivation along the NE Atlantic margin. Journal of the Geological Society, I54(I), pp.85-92.

Edwards, A., O'Connor, S., Kelly, P., Heller, J., Odesanya, F., Green, S., Hoskin, E., and Diaz, M. The West of Shetlands Regional Pressure Study. Non-proprietary regional study.

Edwards, A., O'Connor, S., Swarbrick, R., Alderson, A. and Diaz, M. 2012. Overpressure mapping in the West of Shetlands Basin. Abstract, PETEX, London.

Eide, C.H., Schofield, N., Lecomte, I., Buckley, S.J. and Howell, J.A., 2018. Seismic interpretation of sill complexes in sedimentary basins: implications for the sub-sill imaging problem. Journal of the Geological Society, 175(2), Pp. 193-209.

Ellis, D., Jolley, D. W., Passey, S. R. \& Bell, B. R. 2009. Transfer zones: The application of new geological information from the Faroe Islands applied to the offshore exploration of intra basalt and subbasalt strata. In: Varming, T. \& Ziska, H (eds) Faroe Islands Exploration Conference: Proceedings of the $2^{\text {nd }}$ conference. Annals Societatis Scientiarum Faerensis, Supplementum. 50, 205-226. 
Fan, C., Wang, Z., Wang, A., Fu, S., Wang, L., Zhang, Y., Kong, H. and Zhang, X., 2016. Identification and calculation of transfer overpressure in the northern Qaidam Basin, northwest China. AAPG Bulletin, 100(I), pp.23-39.

Fleet, A. J., \& Boldy, S. A. (Eds.). (1999). Petroleum geology of northwest Europe: Proceedings of the 5th Conference. Geological Society of London.

Gibb, F.G.F. and Kanaris-Sotiriou, R., 1988. The geochemistry and origin of the Faeroe-Shetland sill complex. Geological Society, London, Special Publications, 39(I), Pp.24I-252.

Grace, R.D., 2017. Blowout and well control handbook. Gulf Professional Publishing.

Grauls, D.J., and Baleix, J.M., 1994, Role of overpressures and in situ stresses in fault-controlled hydrocarbon migration: A case study: Marine and Petroleum Geology, v. II, p. 734-742, doi: 10.1016/02648172(94)90026-4.

Grant, N., Bouma, A., and McIntyre, A. 1999. The Turonian play in the Fareo-Shetland basin, in Fleet, A.J. and Boldy, S.A.R. eds., Petroleum Geology of Northwest Europe: Proceedings of the $5^{\text {th }}$ Conference, London, The geological Society, London, 661-673.

Grove, C., 2013. Submarine hydrothermal vent complexes in the Paleocene of the Faroe-Shetland Basin: Insights from three-dimensional seismic and petrographical data. Geology, 4I(I), pp.7I-74.

Hardman, J. P. A., Schofield, N., Jolley, D. W., Holford, S. P., Hartley, A. J., Morse, S., Underhill, ～J. $\quad$ R., Watson, D. A. \& Zimmer, E. H. 2018a. Prolonged dynamic support from the Icelandic plume of the NE Atlantic Margin. Journal of the Geological Society, London. First Published Online: https://doi.org/10.1144/igs2017-088

Hardman, J., Schofield, N., Jolley, D., Hartley, A., Holford, S. \& Watson, D. 2018b. Controls on the distribution of volcanism and intra-basaltic sediments in the Cambo-Rosebank region, West of Shetland. Petroleum Geoscience, First Published Online: $\quad$ https://doi.org//0.1144/petgeo2017$\underline{061}$

Hitchen, K. and Ritchie, J.D., 1987. Geological review of the West Shetland area. Petroleum Geology of North West Europe. Graham \& Trotman, London, 737, p.749.

Hoskins, E., O'Connor, S., Robertson, S., Streit, J., Ward, C., Lee, J. and Flett, D. Influence of faulting on reservoir overpressure distribution in the Northern Carnarvon Basin. APPEA Journal, I-I3.

Illife, J.E., Robertson, A.G., Ward, G.H.F., Wynn, C., Pead, S.D.M., and Cameron, N. 1999. The importance of fluid pressures and migration to the hydrocarbon propectivity of the Fareo-Shetland White Xone, in Fleet, A.J. and Boldy, S.A.R. eds., Petroleum Geology of Northwest Europe: Proceedings of the $5^{\text {th }}$ Conference, London, The geological Society, London, 60I-6II.

Lahann, R.W., McCarty, D., and Hsieh, J., 200I, Influence of Clay Diagenesis on Shale Velocities and Fluid Pressure, Offshore Technology Conference (OTC 13046).

Lamers, E., and Carmichael, S.M.M. 1999. The Paleocene deepwater sandstone play of West of Shetlands, in Fleet, A.J. and Boldy, S.A.R. eds., Petroleum Geology of Northwest Europe: Proceedings of the $5^{\text {th }}$ Conference, London, The geological Society, London, 645-659.

Luo, X. and Vasseur, G. 2016. Overpressure dissipation mechanisms in sedimentary sections consisting of alternating mud-sand layers. Marine and Petroleum Geoscience, 78 883-894.

Mann, D.M. and Mackenzie, A.S., 1990. Prediction of pore fluid pressures in sedimentary basins. Marine and Petroleum Geology, 7(I), pp.55-65.

Mark, NJ., Schofield, N., Pugliese, S., Watson, D., Holford, S., Muirhead, D., Brown, R. and Healy, D. (2017) 'Igneous intrusions in the Faroe Shetland basin and their implications for hydrocarbon exploration: new insights from well and seismic data'. Marine and Petroleum Geology. DOI: 10.1016/J.MARPETGEO.2017.12.005

Moy, D.J. and Imber, J., 2009. A critical analysis of the structure and tectonic significance of rift-oblique lineaments ('transfer zones') in the Mesozoic-Cenozoic succession of the Faroe-Shetland Basin, NE Atlantic margin. Journal of the Geological Society, 166(5), pp.831-844.

Mudge, D. C. 2014. Regional controls on Lower Tertiary sandstone distribution in the North Sea and NE Atlantic margin basins. In: McKie, T. Rose, P. T. S. Hartley, A. J. Jones, D.

W. \& Armstrong, T. L. (eds) Tertiary Deep-Marine Reservoirs of the North Sea Region. Geological Society, London, Special Publications, 403, 17-42. 
Neglia, S., 1979. Migration of fluids in sedimentary basins. AAPG Bulletin, 63(4), pp.573-597.

Ogilvie, S., Barr, D., Roylance, P. and Dorling, M., 2015. Structural geology and well planning in the Clair Field. Geological Society, London, Special Publications, 42I(I), pp. 197-2I2.

Osborne, M.J. and Swarbrick, R.E., 1997. Mechanisms for generating overpressure in sedimentary basins: A reevaluation. AAPG bulletin, 8I(6), Pp. 1023-104I.

Rateau, R., Schofield, N. and Smith, M., 2013. The potential role of igneous intrusions on hydrocarbon migration, West of Shetland. Petroleum Geoscience, 19(3), Pp.259-272.

Rider, M., Kennedy, M., 20II. The Geological Interpretation of Well Logs, third ed. RiderFrench Consulting Ltd, Glasgow.

Ritchie, J.D., Johnson, H., Quinn, M.F. and Gatliff, R.W., 2008. The effects of Cenozoic compression within the Faroe-Shetland Basin and adjacent areas. Geological Society, London, Special Publications, 306(I), Pp. I2I-136.

Ritchie, J.D., Ziska, H., Johnson, H. and Evans, D., 20II. Geology of the Faroe-Shetland Basin and adjacent areas. Ruth P.J. van , Hillis R.R. Swarbrick R.E., 2002, Detecting overpressure using porosity-based techniques in the Carnarvon Basin, Australia. The APPEA Journal 42, 559-569.

Schofield, N.J., Brown, D.J., Magee, C. and Stevenson, C.T., 2012. Sill morphology and comparison of brittle and non-brittle emplacement mechanisms. Journal of the Geological Society, I69(2), pp. I27-I4I.

Schofield, N., Holford, S., Millet, J., Brown, D., Jolley, D., Passey, S.R., Muirhead, D., Grove, C., Magee, C., Murray, J., Hole, M., Jackson, C.A.-L., Stevenson, C., 2015. Regional magma plumbing and emplacement mechanisms of the Faroe-Shetland Sill Complex: implications for magma transport and petroleum systems within sedimentary basins. Basin Res. 19. http://doi.org//0.1 III/bre. 12164.

Schofield, N., Jolley, D., Holford, S., Archer, S., Watson, D., Hartley, A., Howell, J.,Muirhead, D., Underhill, J., Green, P., 2017, Challenges of future exploration within the UK Rockall Basin. In: Geological Society, London, Petroleum Geology Conference Series, vol. 8. Geological Society of London, Pp. PGC8-37.

Scotchman, I. 200I. Petroleum geochemistry of the Lower and Middle Jurassic in Atlantic margin basins of Ireland and the UK. In: Shannon, P.M., Haughton, P.D.W. \& Corcoran, D.V. (eds). The petroleum exploration of Ireland's Offshore Basins, Geological Society of London, London, Special Publications I88, 3I-60.

Scotchman, I.C., Doré, A.G. and Spencer, A.M., 2018, January. Petroleum systems and results of exploration on the Atlantic margins of the UK, Faroes \& Ireland: what have we learnt?. In Geological Society, London, Petroleum Geology Conference series (Vol. 8, No. I, pp. 187-197). Geological Society of London.

Senger, Kim, et al. "Geometries of doleritic intrusions in central Spitsbergen, Svalbard: an integrated study of an onshore-offshore magmatic province with implications for $\mathrm{CO} 2$ sequestration." Geological controls on fluid flow and seepage in western Svalbard fjords, Norway. An integrated marine acoustic study (2013).

Senger, K., Buckley, S..., Chevallier, L., Fagereng, A., Galland, O., Kurz, T.H., Ogata, K., Planke, S. and Tveranger, J., 2015. Fracturing of doleritic intrusions and associated contact zones: Implications for fluid flow in volcanic basins. Journal of African Earth Sciences, 102, pp.70-85.

Stoker, M.S. 2016. Cretaceous tectonostratigraphy of the Faroe-Shetland region. Scottish Journal of Geology, https://doi.org/10.1144/sjg2016-004

Stoker, M.S., Holford, S.P., Hillis, R.R., Green, P.F. and Duddy, I.R., 2010, Cenozoic post-rift sedimentation off northwest Britain: Recording the detritus of episodic uplift on a passive continental margin. Geology, 38 , 595-598.

Swarbrick, R.E., Osborne, M.J. and Yardley, G.S., 200I, AAPG Memoir 76, Chapter I: Comparision of Overpressure Magnitude Resulting from the Main Generating Mechanisms.

Svensen, H. H., Polteau, S., Cawthorn, G., \& Planke, S. (2018). Sub-volcanic intrusions in the Karoo basin, South Africa. In Physical Geology of Shallow Magmatic Systems (pp. 349-362). Springer, Cham.

Tassone, D.R., Holford, S.P., Stoker, M.S., Greem P., Johnson, H., Underhill, J.R. and Hillis, R.R. 2014. Constraining Cenozoic exhumation in the Faroe-Shetland region using sonic transit time data. Basin Research, 26, 38-72.

Tingate, P.R., Khaksar, A., van Ruth, P., Dewhurst, D.N., Raven, M.D., Young, H., Hillis, R. R., and Dodds, K. 2001. Geological controls on overpressure in the Northern Carnarvon Basin. APPEA Journal 573-593. 
Tingay, M.R., Hillis, R.R., Swarbrick, R.E., Morley, C.K. and Damit, A.R., 2007, 'Vertically transferred'overpressures in Brunei: Evidence for a new mechanism for the formation of high-magnitude overpressure. Geology, 35(I I), pp.1023-1026

Tingay, M.R., Morley, C.K., Laird, A., Limpornpipat, O., Krisadasima, K., Pabchanda, S. and Macintyre, H.R., 2013. Evidence for overpressure generation by kerogen-to-gas maturation in the northern Malay Basin. AAPG bulletin, 97(4), pp.639-672.

Tingay, 2015, Initial pore pressures under the Lusi mud volcano, Indonesia. Interpretation, 3, 33-49.

Traugott, Martin O., and Phillip D. Heppard. "Prediction of pore pressure before and after drilling-Taking the risk out of drilling overpressured prospects." AAPG Hedberg Research Conference. Vol. 70. 1994.

Van Ruth, P.J., Hillis, R.R., Swarbrick, R. and Tingate, P. 2000. Mud weights, transient pressure tests and the distribution of overpressue in the North West Shelf, Australia, Petroleum Exploration Society Australia Journal 28, 59-66.

Watson, D., Schofield, N., Jolley, D., Archer, S., Finlay, A. J., Mark, N., Hardman, J. \& Watton, $\quad$ T. 2017. Stratigraphic overview of Palaeogene tuffs in the Faroe-Shetland Basin, NE Atlantic Margin. Journal of the Geological Society, London, I 74, 627-645.

Westbrook, G. K., and M. J. Smith. "Long decollements and mud volcanoes: Evidence from the Barbados Ridge Complex for the role of high pore-fluid pressure in the development of an accretionary complex." Geology II.5 (1983): 279-283.

White, R. and McKenzie, D., 1989, Magmatism at rift zones: the generation of volcanic continental margins and flood basalts. Journal of Geophysical Research: Solid Earth, 94(B6), pp.7685-7729

Nick Schofield is a Senior Lecturer in Igneous and Petroleum Geology at the University of Aberdeen, where he leads the Atlantic Margin Research Group. He has published $\sim 50$ papers on sill emplacement and the interaction of volcanism with petroleum systems. Nick has a PhD from the University of Birmingham and a BSc(Hons) from the University of Edinburgh

Simon Holford is Associate Professor of Petroleum Geoscience at the University of Adelaide's Australian School of Petroleum, where he co-leads the Stress, Structure \& Seismic Research Group. Simon has published $\sim 90$ papers on the prospectivity and tectonics of margins, petroleum geomechanics and magmatism in basins. Simon has a PhD from the University of Birmingham and a BSc(Hons) from Keele University.

Alex Edwards is the Global Portfolio Manager for Wells at lkon Science, having joined in 2009. $\mathrm{He}$ has been involved in all aspects of regional pore pressure analysis, pre- and post well analysis. Alex received a MESci in geology (2005) from the University of Liverpool and a PhD in structural geology at the University of Manchester.

Niall Mark completed his $\mathrm{PhD}$ in Interaction of Igneous Intrusions with Petroleum Systems in 2019. He received a MSc in Hydrocarbon Exploration from the University of Aberdeen in 2014 and a BSc(Hons) in Earth Science from Glasgow University in 2012.

Stefano Pugliese is Lead Geoscientist with Chrysaor in the UK. He received his BSc geology degree from the University of St. Andrews and a Ph.D. in igneous geology from Kingston University. His petroleum career began in Vietnam looking at fractured basement plays but over the last decade, has focused on the traditional Cenozoic and Mesozoic plays of the North Sea. 


\section{Acknowledgments}

JX Nippon UK Ltd are thanked for PSDM seismic data used in this study. Well data is from the Common Access Database (CDA). IHS Kingdom Software and Schlumberger Petrel advice.

Figure I - Tectonic elements of the Faroe-Shetland Basin. Adapted from Ellis et al. (2009), Mudge (2014), Watson et al. (2017) and Hardman et al. (2018a,b). Wells that contain evidence for overpressured intrusions are labelled. Map in Mercator/ED50 datum.

Figure 2 - Regional seismic line through well 2I4/28-I. Data courtesy of PGS - FSB MegaSurvey plus.

Figure 3 - Velocity vs. Density cross-plot for well 2/4/28-I. Examining velocity and density relationships can reveal information about the mechanism of overpressure development (Lahann et al., 200I following the work of Bowers, 1994, 1995). The deepest shales (Cretaceous age) do not deviate from the Gardener shale trend, which is indicative of disequilibrium compaction as the sole pressure mechanism. The density values, however, exceed $2.45 \mathrm{~g} / \mathrm{cm} 3$ (typical maximum density due to mechanical compaction) which suggests low porosity shales. The corrected bottom hole temperature $(\mathrm{BHT})$ is $167^{\circ} \mathrm{C}\left(332^{\circ} \mathrm{F}\right)$ and therefore the high-density values correspond to diagenetic shale alteration.

Figure 4 - Seismic line through Well 2/4/28-I located in the Faroe-Shetland Basin, offshore NW Scotland. The seismic line is from a 3D cube acquired 20II-20I2 and reprocessed to Pre-Stack Depth Migration in 2016. The lower zone of intrusions, where overpressure was encountered (Fig. 5 and 6), extend in a down-dip direction towards a depth of $\sim 6.5 \mathrm{~km}(21,325 \mathrm{ft})$.

Figure 5 - Pressure vs depth plot. Direct pressure data (e.g. RFT) from well 2I 4/28-I and well 2I 4/27-I (located $10 \mathrm{~km}$ away, that penetrated same stratigraphic succession). 
Figure 6 - Diagram showing log responses, static mud weight (MPa) and total gas from the lower zone of intrusions where overpressure was encountered in well 2/4/28-I.

Figure 7 -2D seismic line (NS92202) across Well 219/28-2Z, showing inclined intrusion which was penetrated at $3048 \mathrm{mBRT}(\sim 3 . \mathrm{I} \mathrm{sec}$ TWT).

Figure 8 - Detail of a sill penetrated at $3148 \mathrm{mBRT}$. An RFT measurement taken at the sill edge recorded a pressure of $48 \mathrm{MPa}(6,956 \mathrm{Psi})$, some $8 \mathrm{MPa}(\mathrm{I}, 160 \mathrm{Psi})$ higher than the surrounding sequences. This pressure was equivalent to that recorded in RFT measurements at the base of the well (see main text for details). This suggests that the sill penetrated at $3148 \mathrm{mBRT}(10,328 \mathrm{ft} B R T)$ was in pressure communication with deeper units.

Figure 9 - Pressure vs. Depth plot for well 219/28-2Z

Figure 10 - Wireline and FMI log through a $27 \mathrm{~m}(88 \mathrm{ft})$ thick igneous intrusion located within the FaroeShetland Basin (2/3/27-2). Clear fractures can be observed within the intrusion on the FMI log. We interpret the sub-vertical fractures, which extend $>30^{\circ}$ around the circumference of the hole, to be primary cooling fractures and not drilling induced, as no sub-vertical fractures are seen in the weaker shales horizons above and below the intrusion, and no change in mud weight occurred while drilling from the shale through to the intrusion. Note the increased separation of the Deep and Medium Resistivity wireline measurements within the heavily fractured area of the intrusion (from $3270 \mathrm{~m}$ down), and how this separation is greatly reduced within the zone of minimal fracturing towards the top of the intrusion and within the claystone sequence.

Figure II - Seismic Line through the $6.1 \mathrm{~m}(20 \mathrm{ft})$ thick intrusion penetrated by $214 / 28-\mathrm{I}$, highlighting the continuous path that that can be traced vertically and horizontally through the intrusive body from point of intersection at 4,596 mBRT (I5,078 ft BRT) to a larger intrusive complex at depths $>6 \mathrm{~km}(\sim 20,000 \mathrm{ft})$.

Figure 12 A) Diagram showing concept of the Centroid, which is commonly used to explain overpressure within sand bodies as a result of becoming inclined post-deposition (see Traugott and Heppard, 1994; Swarbrick and Osborne, 1998) B) The modified concept of lateral drainage through a fractured intrusion. It is important to note that unlike the concept of the centroid, which relies on recent tilting of the sand body to produce differential pressures, in the case of intrusions, it is their cross-cutting and tendency to intrude sub-vertically which leads to the pressure transfer and drainage, if connected at depth to more overpressured units.

Figure 13 - Conceptual diagram showing the principle of pressure transmission through a fractured igneous intrusive complex. Such a process can lead to overpressure being transferred laterally (and vertically) through a basin $10 \mathrm{~s}$ of $\mathrm{km}$ away from its point of origin. 


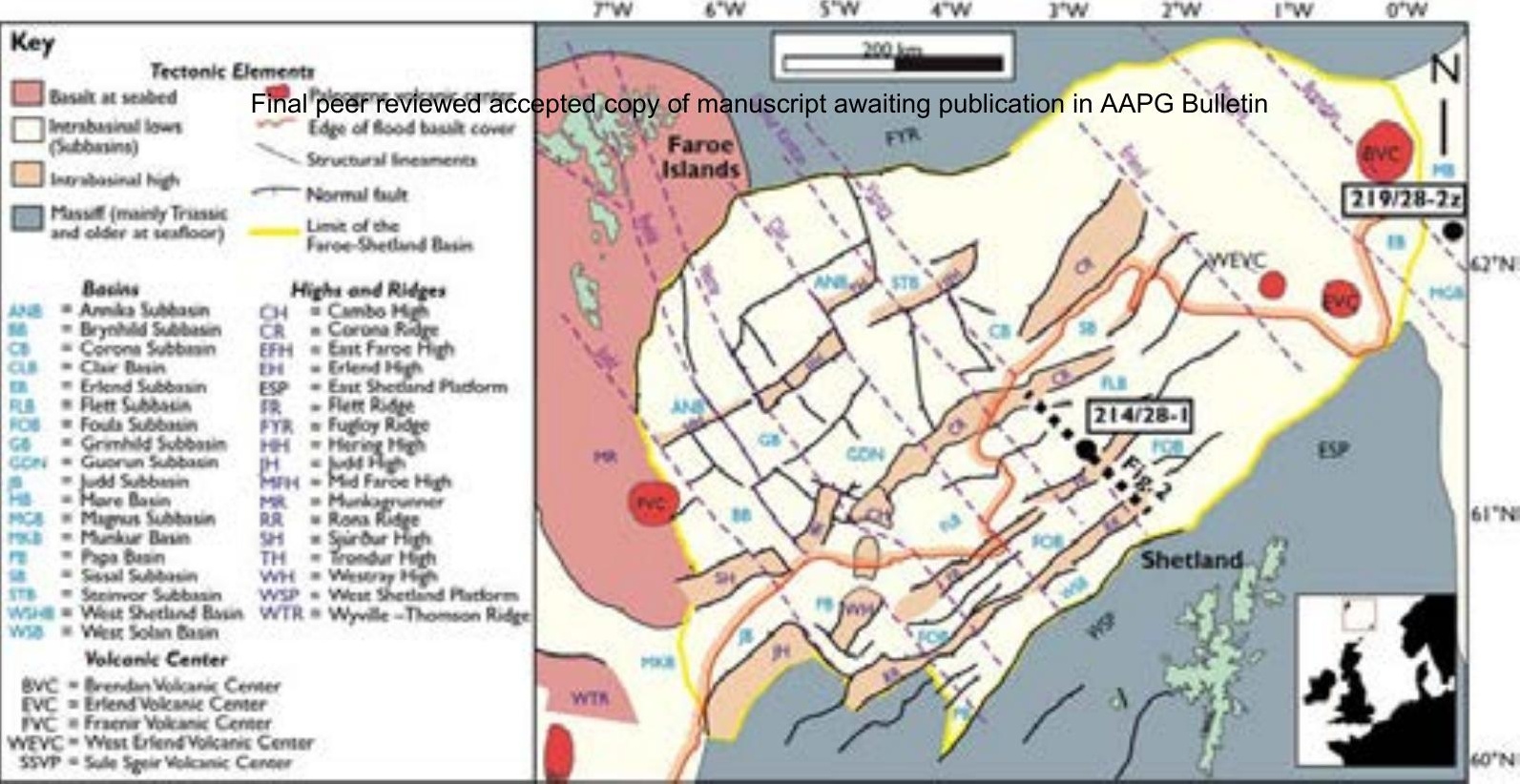


Well 214/28-1

Degen

peer revilewed accepted copy of manuscript awaiting publication in AAPG B

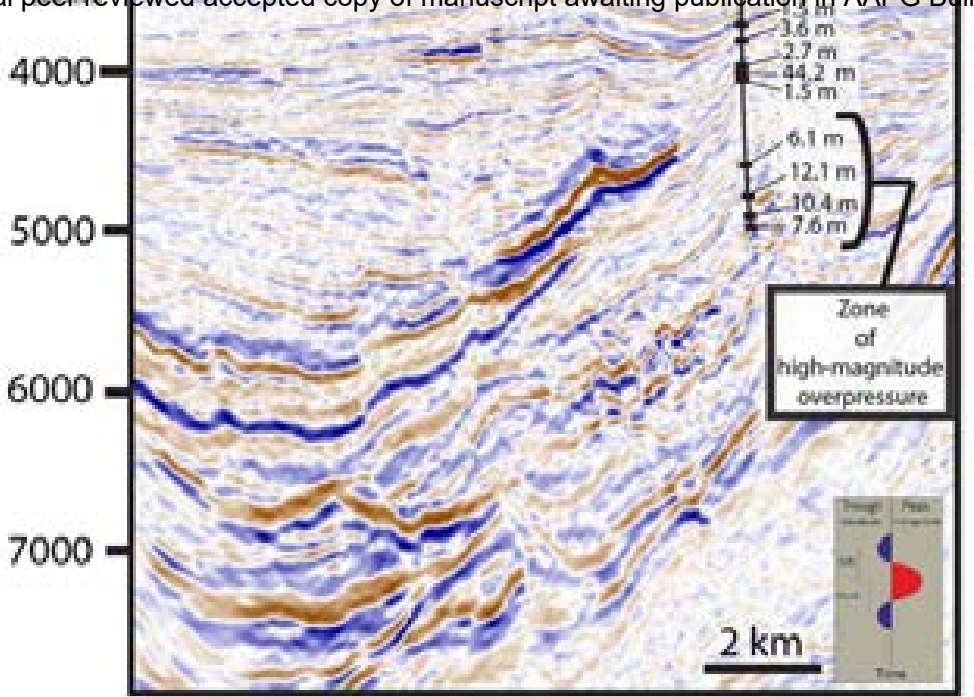





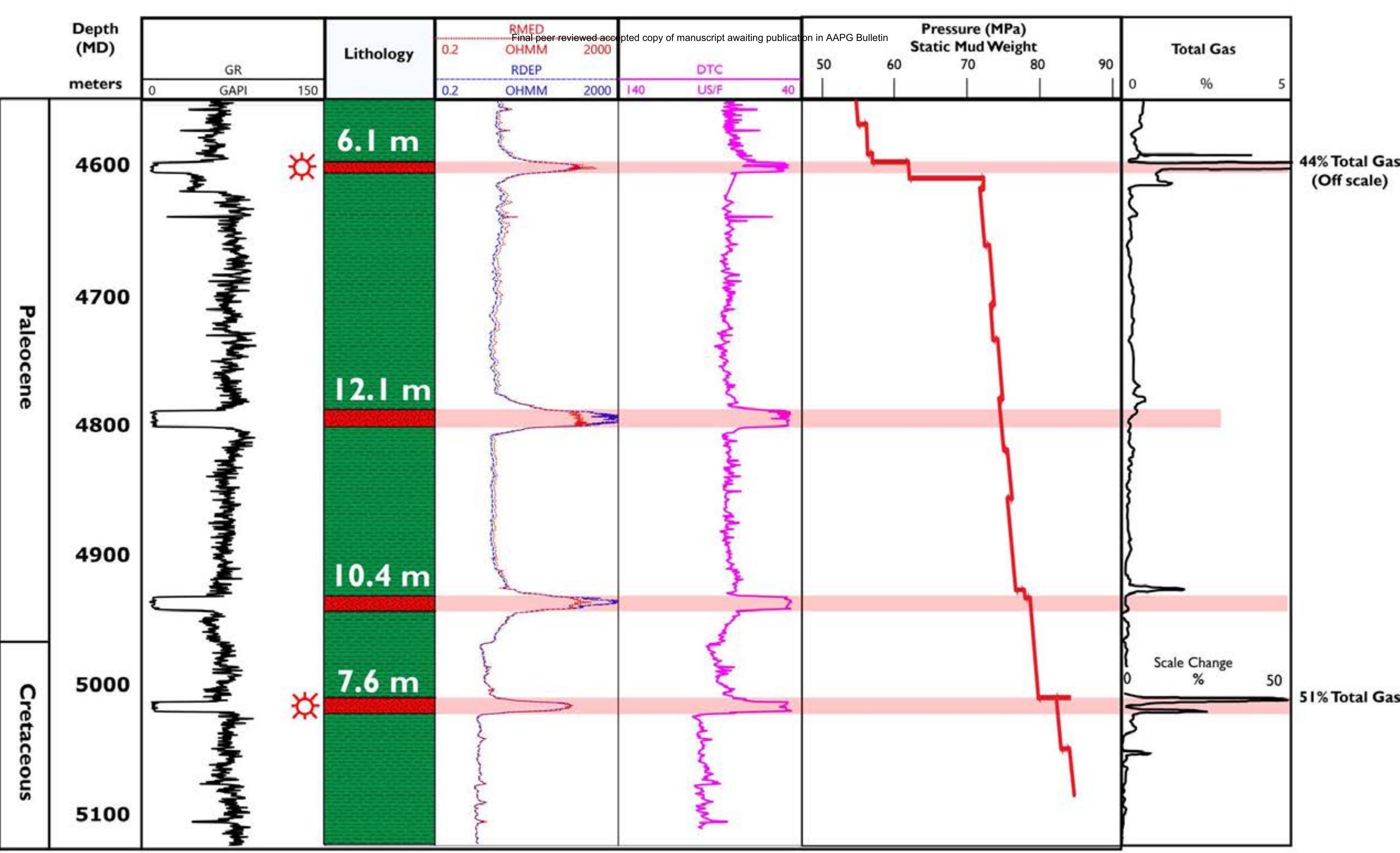




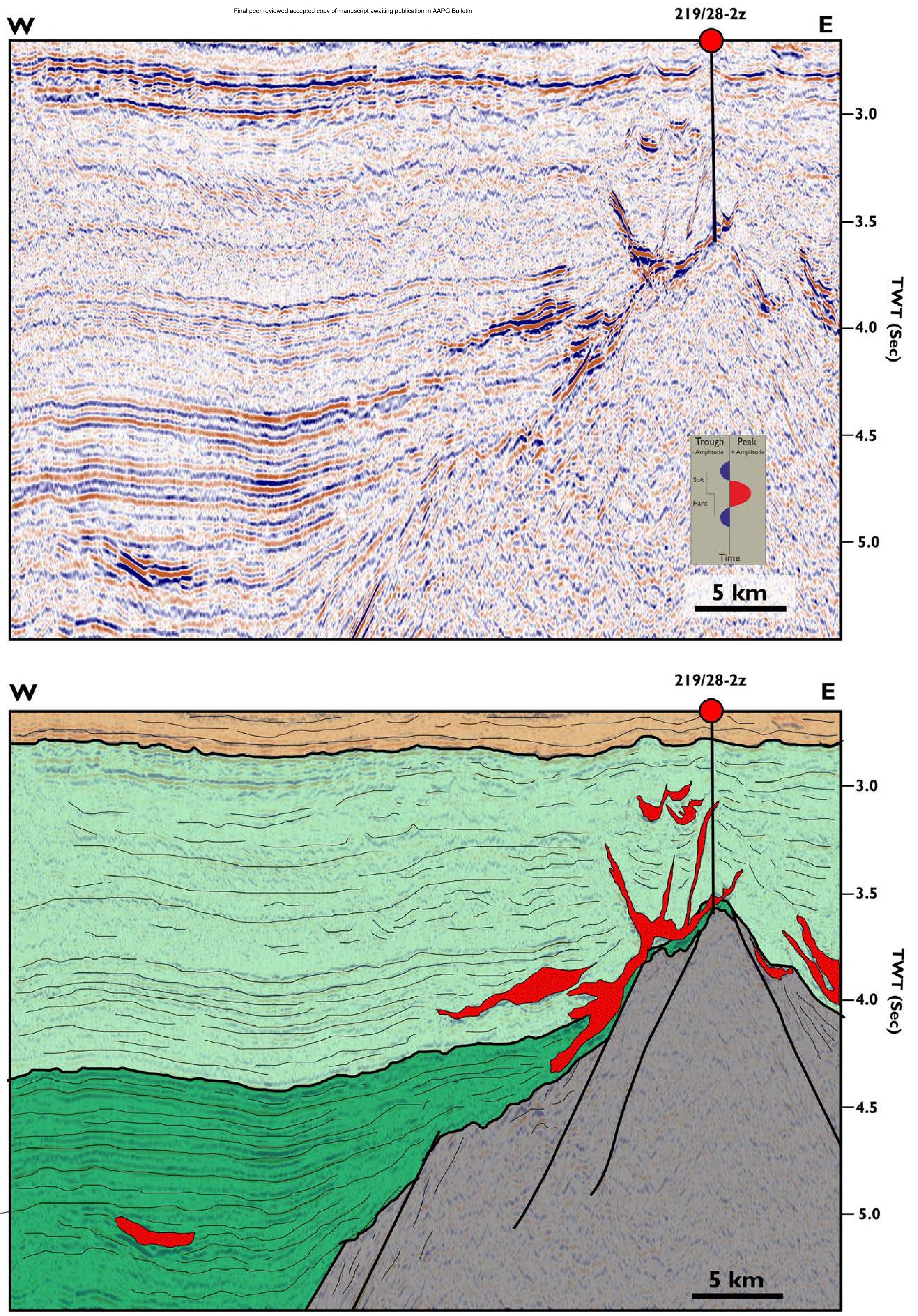




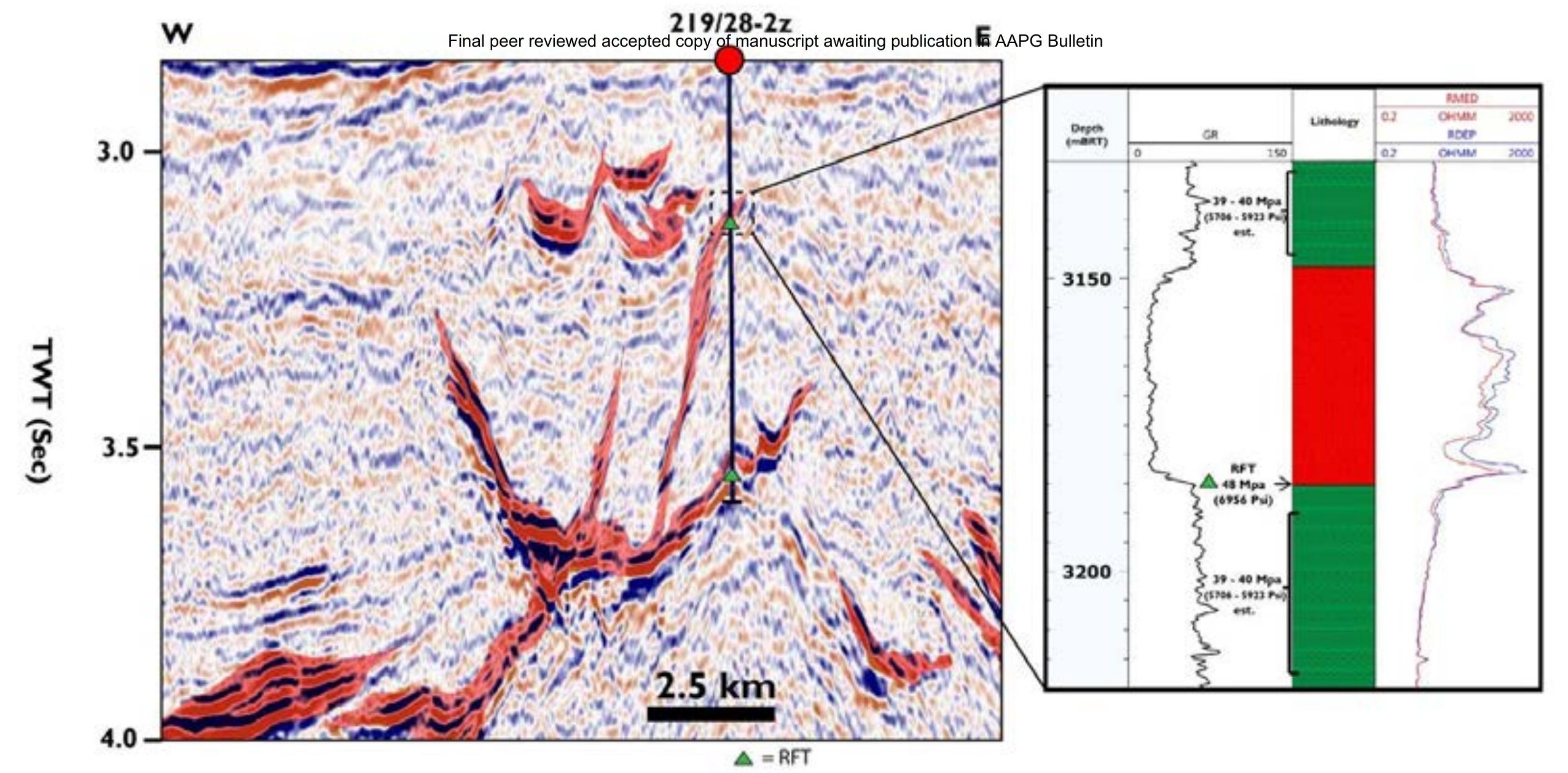





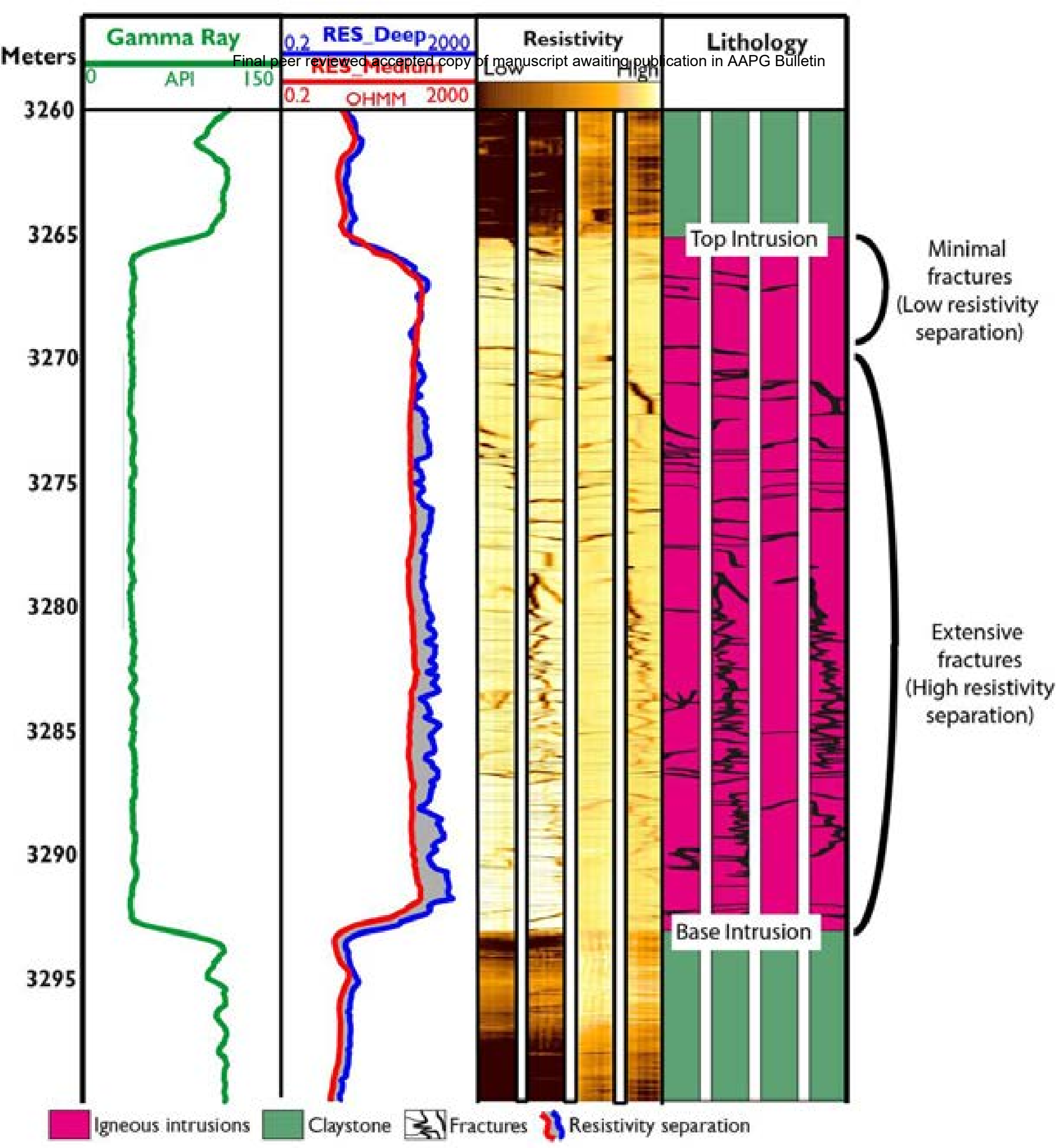




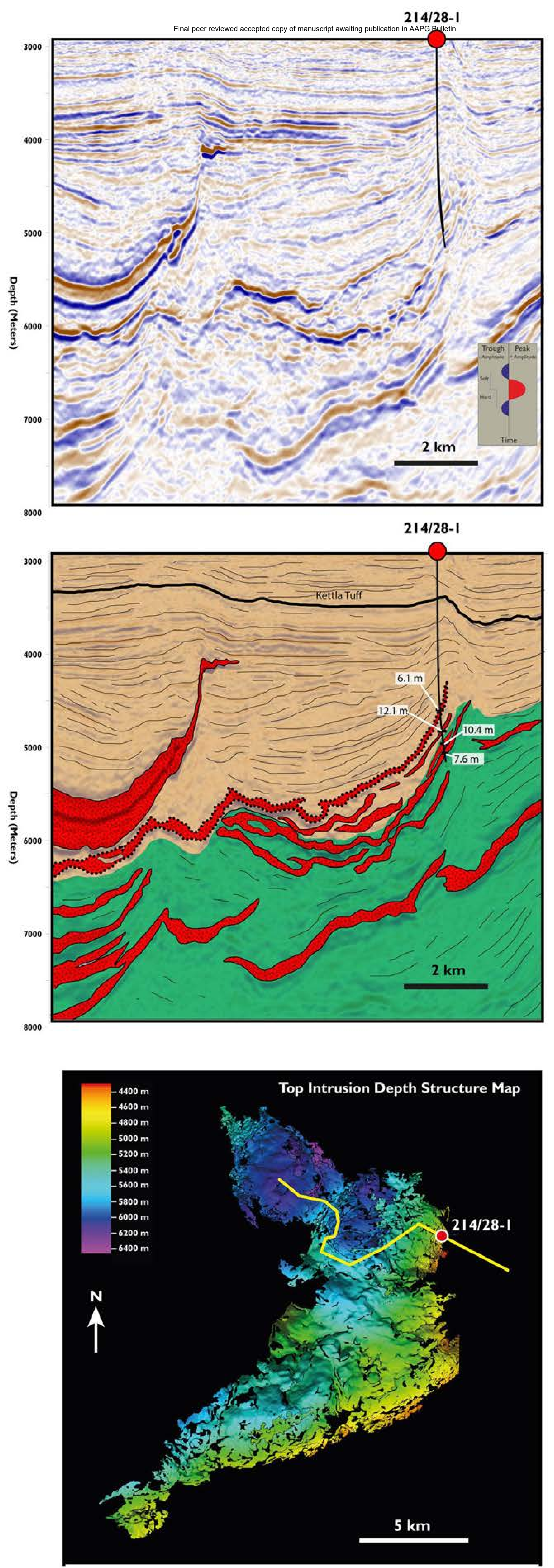




$$
\frac{\pi}{4}
$$




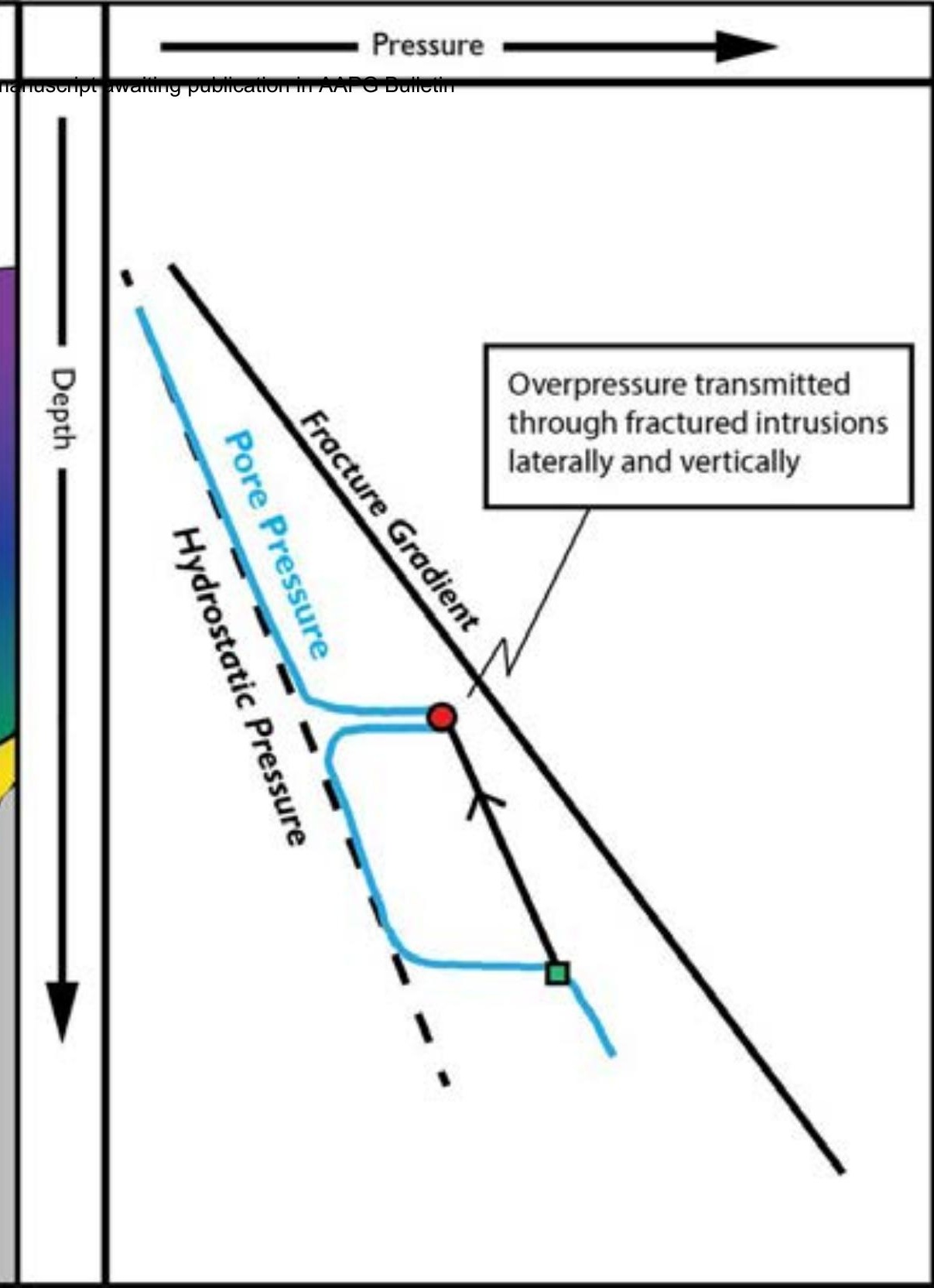

